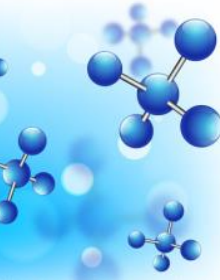

Article

\title{
Correlation Of Calcium Levels With The Strenght Of Uterus Contraction On The Active Phase Of First Stage Labor
}

\author{
Novia Rita Aninora ${ }^{1}$, Joserizal Seridji ${ }^{2}$, Meilinda Agus ${ }^{3}$ \\ ${ }^{1}$ Postgraduate Program of Midwifery, Faculty of Medicice, Andalas University, Indonesia \\ ${ }^{2}$ Department of Obstetrics and Gynecology, Dr. M. Djamil Padang Hospital, Indonesia \\ ${ }^{3}$ Postgraduate Program of Midwifery, Faculty of Medicice, Andalas University, Indonesia
}

\section{SUBMISSION TRACK}

Recieved: March 28, 2017

Final Revision: May 03, 2017

Available Online: May 15, 2017

\section{KEYWORDS}

Calcium Levels, The Stage I of Labor Active

Phase, The strength of uterine contractions

\section{CORRESPONDENCE}

Phone: 085215811492

E-mail: noviarita13@gmail.com

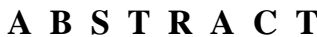

Contributing factor to uterus contraction mechanism is the imbalance of the extracellular calcium level. When extracellular calcium level is inadequate, response of the myometrium to oxytocin decreased and the calcium influx inter-cell membranes are suppressed, thus inhibit uterine contractions. The aim of this research is to know the correlation between levels of calcium and the strength of uterine contraction in the active phase of first stage labor. This was a cross-sectional analytic correlative study in the Dr. Rasidin Hospital Padang and UPTD Health Laboratory in West Sumatra province, in was conducted from November $1^{\text {st }}, 2014$ till February 2016. Sampling was takes by using non probability sampling with consecutive sampling. Subjects of this research were the active phase of first stage labor of 62 people. Kolmogorof Smirnov normality test was used to the normality of the data. Pearson correlation test was conducted to examine the correlation between dependent and independent variables. Mean levels of calcium in the the stage I of labor respondents active phase $(8.94 \pm 0,71)$, while mean strength of uterine contractions in active phase of first stage labor $(56.77 \pm 11,84)$, there was positive correlation $(\mathrm{r}=$ 0,62 ) between the levels of calcium in the strength of uterine contractions $(p<0.05)$. The conclusion of the study there was a significant correlation between the levels of calcium in the strength of uterine contractions.

\section{INTRODUCTION}

The process of childbirth and labor is influenced by five factors, namely the passenger in the form of the fetus and placenta (passanger), the factor of birth (passage) strength (power) which includes uterine contraction, maternal position, 
and psychological response. If this factor is in good condition, healthy and balanced then the labor process will take place normally / spontaneously (JNPK-KR, 2008).

Data from the West Sumatra Provincial Health Office shows that there is a decrease in the incidence of maternal deaths, although it is still relatively high. Based on the latest data published, in 2013 maternal deaths in West Sumatra were 90 people, lower than the previous year in 2012 as many as 99 people and in 2011 as many as 129 people. Maternal mortality was caused by haemorrhage (32\%), eclampsia (14\%), prolonged labor (12\%), infection (11\%), abortion (14\%), heart disease (5\%), and others (12\%) Maternal bleeding occurs due to placental retention, severe anemia, prolonged labor, and others (City Health Profile, 2013).

At Rasidin Padang Hospital, the period 1 January 2013 - 31 December 2013 contained 265 deliveries. Most deliveries occur in the 1st parity (42\%), with normal parturition occurring at $58 \%$. Primiparious will increase the risk of prolonged labor by 2 times compared to multiparous women. The duration of parturition is the highest incidence at the age of 19-34 years, and in the first parity of all long-term labor events (Medical Record of Rasidin Hospital, 2013).

The cause of the death of 1 in 3 mothers in West Sumatra is prolonged labor, namely labor that lasts more than 24 hours. Problems must be identified and addressed before the 24 hour deadline is reached. Most of the old parturition shows an extended of first stage. The main cause of prolonged labor is cephalopelvic disproportion, malpresentation and malposition and inefficient uterine work, including a stiff cervix. Prolonged labor can lead to haemorrhage in either labor women or postpartum women. Besides that, in long-term baby babies can also cause asphyxia, which is the biggest cause of infant mortality in West Sumatra (Mariati et al. 2011).

Hypotonic uterine inertia or hypotonic uterine inertia causes labor to cease and the fetus is displaced due to its abnormality in the mother's uterus, in the form of inadequate force to open the cervix or push the fetus out. One of the causes of his disorder is anemia that occurs during pregnancy (Smith, R, 2007).

A 2009 Lartey study found estrogen was able to trigger higher contractility in single fibers of the uterine muscle by increasing the number of oxytocin receptors and $\alpha$-adrenergic agents which modulate the calcium channel membrane. Estrogen is also very necessary in intracellular communication by increasing connexin 43 synthesis and the formation of gap junctions in the myometrium. This condition allows to produce coordinated uterine contractions. In addition estrogen also stimulates the production of prostaglandins F2 $\alpha$ (PGF2 $\alpha$ ) and prostaglandin E2 (PGE2 $\alpha$ ) which stimulates uterine contractions (Linda, J. 2008; Lartey, J, at, el 2009)

A decrease in the concentration of ionized calcium inhibits the myometrial response to oxytocin, with no response to this when calcium levels have been reduced in the myometrium. Conversely, the increase in calcium ion concentration will increase the work of oxytoxin in producing uterine contractions (Mcalpine, J.M, 2015)

The use of calcium with exogenous oxytocin is commonly given to women giving birth and routinely given in clinical cases of primary uterine inertia. Decreasing the availability of physiologically active calcium plays an important role in the pathogenesis and strong uterine contractions dependent on freely ionized calcium into myometrial cells. This is supported clinically, that uterine inertia in childbirth can be stimulated by intravenous administration of calcium gluconate, although the amount of serum calcium is in the normal range (Hollinshead, F.K, at, el.2010).

Calcium levels will increase the level of amplitude and coordination of silent uterine contractions in the trial of ewes and rabbits. It is also determined that the minimum effective dose of exogenous oxytocin produces greater results when given with or after calcium compared to oxytocin alone. (Wray, S, 2007).

Romero's (2006) study concluded that primiparous women are more at risk of complications of pregnancy and childbirth, because the experience of childbirth has never been, then the possibility of abnormalities and complications is quite large both in the strength of his (power), birth canal (passage), and the condition of the fetus (passager). Less information about childbirth can also affect the labor process by extending the duration of labor and increasing the incidence of labor by action, namely labor with cesarean section (OR 0.36, 95\% CI) and vacuum extraction (OR 4.5 CI 95\%).

Research purpose: 
a. To determine the mean level of calcium in labor during the active phase

b. To find out the mean strength of uterine contractions in labor during the active phase

c. To determine the correlation of calcium levels with the strength of uterine contractions in labor during the active phase

\section{METHODS}

The type of research used is analytic with cross sectional research design. The research was carried out in the midwifery room and the laboratory of RSUD Dr. Rasidin Padang and at the UPTD West Sumatra Provincial Health Laboratory Center. The study was conducted from 10 November 2014 to 30 February 2016. The population in this study was all parturients came to give birth in the midwifery room of Rasidin Hospital, Padang, with consecutive sampling technique. Samples taken based on criteria (1) Parties when active phase (opening 3 $-5 \mathrm{~cm}$ ) with intact membranes (2) Fetus live, single, presentation behind head (3) Age of gestational age (4) Pregnancy and childbirth without complications and complications.

Every primiparous mother who came to the Maternity Hospital Rasidin Padang Hospital who met the criteria for admission to the research sample was asked to agree to be included in the study with written informed consent. The mother is given a full explanation of the purpose, benefits and procedure of the study. After giving birth giving consent to be included in the study anamnesis was prepared with a prepared questionnaire. Blood collection is assisted by officers (labor officers, midwives or nurses). The patient is in a sleeping position and not in a contraction state, $3 \mathrm{ml}$ of venous blood is taken, then the spruit is labeled with the patient's identity. To bring the research sample to the UPTD of the West Sumatra Provincial Health
Laboratory, the sample was put in an ice box containing dry ice to keep the sample frozen. Measurements were made using Direct colorimetric complexometric test (Arsenazo III). Measurements of uterine contractions were evaluated for 10 minutes in the phase of maximal dilatation using carditocography (CTG). All examinations were carried out by the person in charge of the room in charge. The reading of the results of the contraction amplitude recording will be requested for help from a gynecological obstetric specialist.

\section{RESULT}

This research was conducted in November 2014 to April 2016, the results of the study were as follows:

In table 5.1 it can be seen that the average age of respondents is in the healthy reproductive age range (27.69 \pm 7.02 years), based on the average parity of respondents parity $(2.15 \pm 1.55$ people $)$, for the mean gestational age respondents are in the range term of gestational age $(38.55 \pm 1.12$ weeks), while the mean duration of delivery of respondents was in the normal timeframe (7.65 \pm 2.27 hours). Statistical test results showed that the age of the respondent, the number of pregnancies of gestational age and length of labor showed no significant differences $(\mathrm{p}=$ $0.00, \mathrm{p}=0.0 .23, \mathrm{p}=0.29, \mathrm{p}=0.25$ ).

Based on the picture In table 5.1 shows the correlation between calcium levels with uterine contractions where the value of $r=0.619$ there is a relationship between calcium levels and uterine contractions and has a positive direction with the closeness of the relationship of 0.384. Based on statistical tests showed that there are between levels of calcium with uterine contractions where the value of $p=0.000<0.05$. This means, that the better the calcium level, the stronger the uterine contraction.

Table 5.1 Characteristics of Research Subjects

\begin{tabular}{llcc}
\hline \multicolumn{1}{c}{ Characteristics } & n & \% \\
\hline 1. & Age (Year old) & 7 & 11,29 \\
$<20$ & 42 & 67,74 \\
$20-35$ & 13 & 20,97 \\
& $>35$ & $27,69 \pm 7,02$ & \\
Mean \pm SD & & 50 \\
2. & Paritas (orang) & 31 & 5
\end{tabular}


$2-4$

$>4$

Mean + SD

3. Gestational Age (weeks)

37

38

39

40

Mean + SD

4. Labor time (Hours)

$<5$

$5-12$

$>12$

Mean+SD
7

$2,15 \pm 1,55$

14

17

14

17

$38,55 \pm 1,12$

7

53

11,29

2

85,49

3,22

$7,65 \pm 2,27$

Gambar 5.1 Scatter Plot hubungan kontraksi uterus dengan kadar kalsium

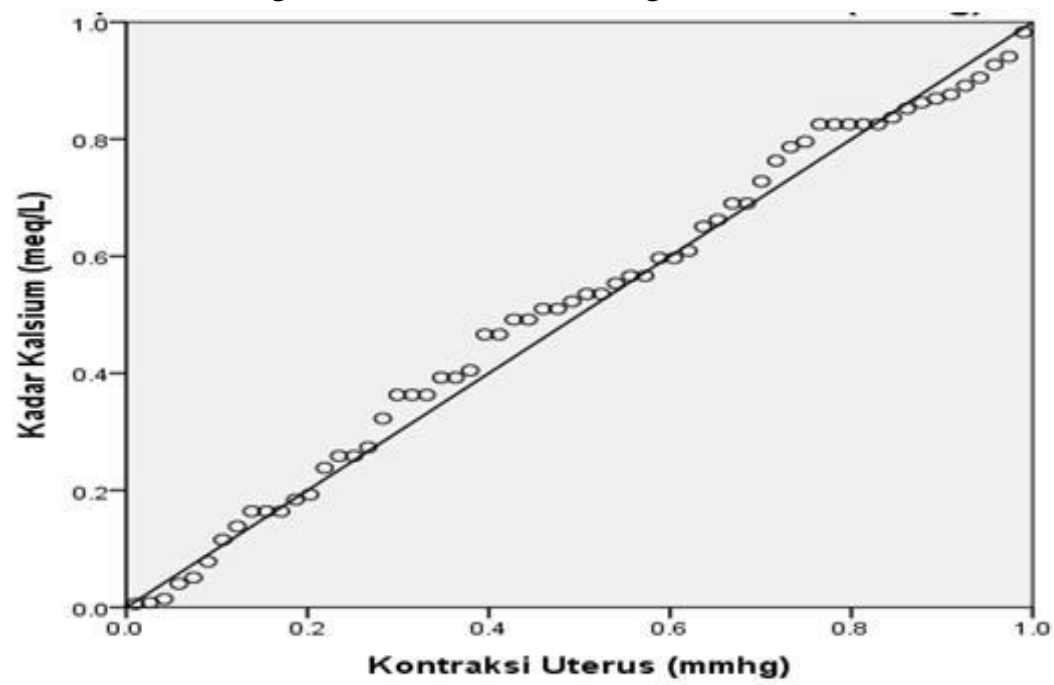





\section{DISCUSSION}

The purpose of the discussion is to interpret The analysis shows that there are 42 mothers who have age in the non-risk category (20-35 years) and there are 20 mothers who have age in the risk category ( $<20$ and $>35$ years), $\rho$ Value obtained from this analysis is 0.09 . The results of the analysis showed that almost half of mothers who have age in the risk category, theoretically age has a relation to the incidence of uterine atony.

According to Prawiroharjo (2009) high-risk pregnancies can arise in conditions of four too (too young, too old, too much, too close). In the risky age group that is $<20$ years $>35$ years and the age group is not at risk or mild risk is 20 years to 35 years. His abnormality is often related to young women and nullipara, maternal age has a contribution to prolonged parturition, because it can cause both maternal and fetal pain (Cunningham, 2013).

On average, mothers who are very young (less than 20 years) do not have enough knowledge about the nutritional needs of a pregnant woman. In addition, mothers who are too young are in dire need of more nutrition.

Mother's age is too old (more than 35 years) so there will be a lot of risks that you might face related to her health condition. Mothers who are too old, physiologically experience decreased organ function such as weakness of the uterine muscles and their contractions. This is what makes the organs more sensitive, especially if there is a collision in the mother's uterus. Bleeding is a possible thing. Bleeding that is too often certainly results in increased nutritional needs of Mother and baby.

The results of this study are in line with the results of the study of Adillia L, Et, al (2006) where age characteristics did not differ in the group of mothers with hypotonic uterine compared to non hypotonic uteri. Fatima's (2013) study found that the mean age of respondents in the hypotonic uterine group was $24.76+6.12$ years compared to the mean age of respondents in the non-hypotonic group at $24.30+4.95$ years. Statistically there were no significant differences between age in the hypotonic uterine group or not hypotonic.

Parity is one of the factors associated with the incidence of uterine inertia. Parity affects the duration of labor and the incidence of complications. In mothers with primipara because of the experience of childbirth has never been, the abnormalities and complications experienced are quite large, such as labor dystocia and also lack of information about childbirth affecting the labor process. Premature labor is more common in the first pregnancy. The occurrence will be reduced by the increase in the number of parity that is sufficiently months up to the fourth parity (Krisnadi et al. 2009). This means there is a relationship between parity and uterine atony..

Mulyani (2014) states that most respondents who have parity $\geq 3$ times more at risk of developing dystocia 24 times greater than respondents who have parity $<3$ times. In this study obtained the fastest delivery time of 4 hours and the longest 13 hours, with an average of $7.83 \pm 2.49$. Most distribution in 9 working hours (18.8\%). The longer the labor, will cause harmful effects for the mother and child. The severity of the injury continues to increase with the length of work, the risk increases rapidly after 24 hours. An increased incidence of uterine atony, lacerations, bleeding, infection, maternal fatigue and shock. A high birth rate exacerbates the danger to mothers (Oxorn, 2010).

The results showed that the average calcium level was $8.94 \pm 0.71$ and the average uterine contraction was $56.77 \pm 11.84$, the Pearson correlation test between calcium levels and uterine contraction (r) 0.61 showed a relationship that positive and significant between levels. calcium with uterine contractions ( $\mathrm{p}<0.05)$. Regression test also shows a strong relationship (r2) of 0.38 .

Gao's research, L.at, el (2009) states that low calcium intake in pregnant women shows a lack of calcium levels is one of the causes of uterine inertia. Calcium is an important component of the diet which is an important regulator of the process of regulating blood vessel function.

Another supporting study is a study by Adillia L, Et, al (2006) that studies serum levels of calcium and magnesium in patients with more hypotonic and without hypotonic uterine inertia, suggesting that patients with serum calcium levels $\leq 8.5 \mathrm{mg} / \mathrm{dL}$, risk Hypotonic uterine inertia during childbirth is 4.17 times higher than serum calcium levels $>8.5 \mathrm{mg} /$ dL.

Fomin VP, at.el (2006) states that subclinical hypocalcaemia may have a large effect on normality and parturition progression. Changes in the function of calcium, metabolism and absorption during pregnancy and birth have a contribution such as the physiological state thereby inhibiting the mother's process of giving birth. 
Wattimury, at.el. (2013) also showed that the total serum levels of calcium and calcium ions in hypotonic uterine inertia were lower than the levels present in normal labor. The strength of smooth muscle contraction depends largely on the level of extracellular calcium.

The basis of the mechanism of uterine contraction is a change in electrical activity. The electric potential difference between the plasma membrane (potential membrane) because of the unequal distribution of ions between intra and extra cells. This condition occurs because of the large amount of negatively charged intracellular biomolecules that cannot escape and selective plasma membrane canals. The ions will move in a direction determined by differences in concentration and membrane potential (City, S. K, At, el 2013, Mcalpine, J. M, at, el, 2015) In this study found 16 respondents with the amplitude of uterine contractions of more than $60 \mathrm{mmHg}$ with normal calcium levels limits, whereas 10 respondents with calcium levels less than normal had normal amperage contraction amplitude. Theoretically, if the level of calcium levels in the blood is too low it will stimulate the parathyroid hormone and cause intracellular calcium ion levels to increase, which will cause the smooth muscle cells of the blood vessels to hyperactive against suppressing substances so that peripheral vascular resistance increases. (Guyton, 2008).

Based on studies conducted by Fischer at, el (2005) suggesting the use of misoprosol for cervical ripening versus control there were visible differences, these women tended to give birth within 48-96 hours and not performed cesarean section (RR 0.85, 95\% confidence interval (CI) $0.58-1.25,11$ trials, 594 women). Misoprostol works by increasing intracellular free calcium.

\section{CONCLUSION}

Based on the results of the study, it was concluded that the mean calcium level in the first respondent in the active phase (8.94 \pm
0.71) $\mathrm{mg} / \mathrm{d}$, the mean strength of uterine contractions in the first respondent in the active phase $(56.77 \pm 11.84) \mathrm{mmhg}$, there was a significant positive correlation between calcium levels and the strength of uterine contractions ( $p<0.05)$.

From the results of research that has been done can be suggested as follows, it is necessary to provide information to pregnant women about the role and needs of calcium during pregnancy along with the provision of calcium supplements for mothers during pregnancy and increased calcium intake in daily meals with various foods that contain high calcium.

\section{REFERENCES}

Acharya, G., Sitras, V., Paulssen, R. H., \& Grønaas, H. (2008). Gene expression profile in labouring and non-labouring human placenta near term, 14(1), 61-65. doi.org/10.1093/molehr/gam083

Aguilar, H. N., \& Mitchell, B. F. (2010). Physiological pathways and molecular mechanisms regulating uterine contractility, 16(6), 725-744. doi.org/10.1093/humupd/dmq016

Albers, L. L. (2007). The Evidence for Physiologic Management of the Active Phase of the First Stage of Labor, 207-215.

Anderson. L (2010). The Myometrial Effects of Progesterone Doctor of Medicine Faculty of Medicine University of Glasgow.

Anwar, A. D., Purwara, B. H., \& Tjahyadi, D. (2015). Serum Calcium And Magnesium Levels Ratio In Patients With And Without Hypotonic Uterine Inertia, 3(2), 1-11.

Arisman M. (2009). Gizi Dalam Daur Kehidupan. Jakarta: EGC.

Bobak IM, Lowdermilk D, Jensen M, P. S. (2005). Buku ajar keperawatan maternitas (terjemahan). Jakarta: EGC.

Breuiller-fouché, M., Dubois, O., Sediki, M., Garcia-verdugo, I., Palaniyar, N., Tanfin, Z., ... Mehats, C. (2010). Secreted surfactant protein A from fetal membranes induces stress fibers in cultured human myometrial cells, 
1188-1197.

doi.org/10.1152/ajpendo.00746.2009.

Cunningham FG, Gant NF, Leveno KJ, Gilstrap LC, Hauth JH, W. K. (2010). OBSTETRICS Williams (23rd ed.). McGrawHill, New York.

Dahlan, M. S. (2009). Besar Sampel dan Cara Pengambilan Sampel Dalam Penelitian Kedokteran dan Kesehatan. Jakarta: Salemba Medika.

David, T. . L. (2007). Manual Persalinan. Jakarta: EGC.

Fetalvero, K. M., Zhang, P., Shyu, M., Young, B. T., Hwa, J., Young, R. C., \& Martin, K. A. (2008). Prostacyclin primes pregnant human myometrium for an enhanced contractile response in parturition, 118(12). doi.org/10.1172/JCI33800.3966

Fischer, D. P., Hutchinson, J. A., Farrar, D., Donovan, P. J. O., Woodward, D. F., \& Marshall, K. M. (2005). Loss of prostaglandin $\mathrm{F} 2 \mathrm{a}$, but not thromboxane, responsiveness in pregnant human myometrium during labour. doi.org/10.1677/JOE-07-0494

Fomin VP, Gibbs SG, Vanam R, Morimiya A, Hurd WW. Effect of magnesium sulfate on contractile force and intracellular calcium concentration in pregnant human myometrium. Am J Obstet Gynecol. 2006;194(5):1384-90.

Gao, L., Cong, B., Zhang, L., \& Ni, X. (2009). Expression of the calcium-activated potassium channel in upper and lower segment human myometrium during pregnancy and parturition, 9, 1-9. doi.org/10.1186/1477-7827-7-27

Gilbert, R.J. (2010). Calcium , parathyroid hormone, oxytocin and $\mathrm{pH}$ profiles in the whelping bitch, doi.org/10.1016/j.theriogenology.2009.12.008

Guyton AC, H. J. (2007). Buku Ajar Fisiologi Kedokteran (11th ed.). Jakarta: EGC.

Heimstad R., MD, Eirik Skogvoll, MD, Lars$\mathrm{A}^{\circ}$ ke Mattsson, MD, Ole Jakob Johansen, MD, Sturla H. Eik-Nes, MD, and Kjell $\mathrm{A}^{\circ}$. Salvesen, M. (2007). Induction of Labor or Serial Antenatal Fetal Monitoring in Postterm Pregnancy, 109(3), 609-617.
Hidayat, A. A. (2009). Metode Penelitian Keperawatan dan Teknik Analisis Data. Jakarta: Salemba Medika.

Hutchings, G., Williams, O., Cretoiu, D., \& Ciontea, S. M. (2009). Myometrial interstitial cells and the coordination of myometrial contractility, $\quad 13(10), \quad 4268-4282$. https://doi.org/10.1111/j.15824934.2009.00894.x

Jenny J.S Sondakh. (n.d.). Asuhan Kebidanan Persalinan \& Bayi Baru Lahir. Jakarta: Erlangga.

Jim Mann-A.Stewart. (2014). Ilmu Gizi (4th ed.). Jakarta: EGC.

Kamel, R. M. (2010). The onset of human parturition, 975-982. doi.org/10.1007/s00404010-1365-9

Kota, S. K., Gayatri, K., Jammula, S., Kota, S. K., Krishna, S. V. S., \& Meher, L. K. (2013). Review Article Endocrinology of parturition, 17(1), 50-59. doi.org/10.4103/22308210.107841

Lartey, J., \& Lo, A. (n.d.). RHO protein regulation of contraction in the human uterus '. doi.org/10.1530/REP-09-0160

Lestari, S. (2008). Pengaruh pemberian preparat sitrulin-malat terhadap konsentrasi asam laktat ibu bersalin, 32(4).

Linda J. H. (2008). At a Glance Sistem Reproduksi (2nd ed.). Jakarta: Erlangga.

Liu, X., Washington, B., Va, D. C., Tai, K., \& National, C. (2007). TRPC1: The link between functionally distinct store-operated calcium channels TRPC1: The link between functionally distinct store-operated calcium channels, (November 2015).doi.org/10.1016/j.ceca.2007.01.013

Macintyre, D., Chan, E., Macintyre, D. A., Chan, E., \& Smith, R. (2007). Myometrial activation - Coordination , connectivity and contractility,

(October 2016).doi.org/10.1017/S0965539507002033

Mariati, A., Masrul, D. S., Arasy, Z. A. F., Hanum, M. H., \& Arma, M. F. (2007). Studi Kematian Ibu dan Kematian Bayi di Provinsi 
Sumatera Barat: Faktor Determinan dan Masalahnya Study of Maternal Mortality and Infant Mortality in West Sumatera Province: Problem and Determinant Factor.

Mcalpine, J. M., Vanderlelie, J. J., \& Anthony, V. (2015). Journal of Women's First Do No Harm : Intrapartum Calcium Loading During Oxytocic Induction of Labor.

Murray Thomson. (2013). The physiological roles of placental corticotropin releasing hormone in pregnancy and childbirth, (November). doi.org/10.1007/s13105-0120227-2

Nihei, O. K., Fonseca, P. C., Rubim, N. M., Bonavita, A. G., Lyra, J. S. P. O., Neves-dossantos, S., ... Alves, L. A. (2010). Modulatory effects of cAMP and PKC activation on gap junctional intercellular communication among thymic epithelial cells.

Noble, D. (2012). The effects of prostaglandin F $2 \alpha$ on the force / calcium relationship in pregnant rat myometrium, (September).

Otaibi, M. Al. (2014). The physiological mechanism of uterine contraction with emphasis on calcium ion, 1(2).

Prawiroharjo, S. (2009). Ilmu Kebidanan (4th ed.). Jakarta: Yayasan Bina Pustaka.

Romero, R., Tarca, A. L., \& Tromp, G. (2006). Using Transcriptomics, 3(6), 739742.doi.org/10.1371/journal.pmed.0030276

SDKI. (2012). Survei Demografi dan Kesehatan Indonesia. Jakarta: Badan Pusat Statistik Badan Kependudukan dan Keluarga Berencana Nasional Kementerian Kesehatan.

Smith, R. C., Mcclure, M. C., Smith, M. A., Abel, P. W., \& Bradley, M. E. (2007). The role of voltage-gated potassium channels in the regulation of mouse uterine contractility, 12, 1-12. doi.org/10.1186/1477-7827-5-41

Trial, A. R. C. (2007). Induction of Labor or Serial Antenatal Fetal Monitoring in Postterm Pregnancy, 109(3), 609-617.

Wattimury, J. dkk. (2013). Total Serum Level of Calcium and Ion Calcium is Lower in Hypotonic Uterine Inertia, 1(3), 145-148.
Wray, S. (2007). Insights into the uterus, 621631. doi.org/10.1113/expphysiol.2007.038125 